\title{
Określenie możliwości zastosowania symulacji komputerowej do przewidywania kierunku przebiegu reakcji podczas załłaczania wód złożowych
}

\author{
The possibility of application of computer simulation to predict the direction of the reaction \\ during injection of reservoir waters
}

\author{
Piotr Jakubowicz, Teresa Steliga, Dorota Kluk, Katarzyna Wojtowicz \\ Instytut Nafty i Gazu - Państwowy Instytut Badawczy
}

\begin{abstract}
STRESZCZENIE: Obecnie praktycznie całość wód wydobytych w procesie eksploatacji węglowodorów zostaje zagospodarowana poprzez zatłoczenie do wyeksploatowanych złóż. Zmiany parametrów fizyczno-chemicznych (pH, potencjału redox, temperatury itp.) wody podczas wydobycia oraz kontakt wody zatłaczanej z obecną w złożu wodą rodzimą i skałą złożową mogą skutkować wytrącaniem cząstek osadów i zawiesin. Powoduje to kolmatację strefy przyodwiertowej i ograniczenie ilości wody możliwej do zatłoczenia odwiertem chłonnym. Z uwagi na wysoki stopień skomplikowania układu woda zatłaczana-woda złożowa-skała zbiornikowa oraz szeroki wachlarz oddziaływań pomiędzy poszczególnymi składnikami dysponowanie danymi analitycznymi nie zawsze pozwala na prawidłową interpretację przebiegu procesów i określenie ich wpływu na przepuszczalność strefy przyodwiertowej. Wykorzystując wyniki analiz fizyczno-chemicznych składu próbek wód separatorowych o zróżnicowanych właściwościach - dwie próbki o niskiej mineralizacji S1K $\left(575 \mathrm{mg} / \mathrm{dm}^{3}\right)$ i S4K (551 mg/dm³), próbka o wysokiej mineralizacji S2K (306 $\left.428 \mathrm{mg} / \mathrm{dm}^{3}\right)$ i próbka o średniej mineralizacji S3K $\left(79858 \mathrm{mg} / \mathrm{dm}^{3}\right)$ - przeprowadzono obliczenia z wykorzystaniem programu PHREEQC dla trzech baz danych: phreeqc.dat, wateq4f.dat oraz pitzer.dat. Stwierdzono, że w przypadku wód o niskiej mineralizacji wyniki uzyskane na podstawie każdej z baz danych są zbliżone dla minerałów występujących we wszystkich bazach. Natomiast w przypadku roztworów o wysokiej mineralizacji pojawiają się wyraźne różnice w otrzymanych rezultatach. Obliczone indeksy rozpuszczalności pozwoliły na określenie kierunku przebiegu reakcji wytrącania/rozpuszczania poszczególnych minerałów w złożu i wskazanie zagrożeń - głównie ze względu na powstające osady związków żelaza - dla pracy odwiertu zatłaczającego. Przeprowadzono także badania laboratoryjne mieszania wód, podczas których zaobserwowano powstawanie osadów tlenków żelaza, mogących uszkadzać strefę przyodwiertową, co potwierdziło dane uzyskane podczas symulacji komputerowych.
\end{abstract}

Słowa kluczowe: wody złożowe, zatłaczanie wód, indeks rozpuszczalności, PHREEQC.

ABSTRACT: Currently, practically the entire volume of water extracted in the process of hydrocarbon exploitation is utilized by injection into deposits. Changes in the physico-chemical parameters ( $\mathrm{pH}$, red-ox potential, temperature, etc.) of the water during extraction and the contact of the injected water with the native water and deposit rock may result in the precipitation of sediment particles and suspensions. It causes clogging of the near=wellbore zone and limits the amount of water that can be injected with the injection well. Due to the high complexity of the system: the injected water-reservoir rock, and a wide range of interactions between individual components, the analytical data does not always allow for the correct interpretation of the course of the processes and determination of their impact on the permeability of the near-well zone. Using the results of physico-chemical analyses of the composition of separator water samples with different properties - two samples with low mineralization S1K $\left(575 \mathrm{mg} / \mathrm{dm}^{3}\right)$ and S4K $\left(551 \mathrm{mg} / \mathrm{dm}^{3}\right)$, a sample with high S2K $\left(306428 \mathrm{mg} / \mathrm{dm}^{3}\right)$ and medium mineralization S3K $\left(79858 \mathrm{mg} / \mathrm{dm}^{3}\right)$ - calculations were performed using the PHREEQC program for the three databases: phreeqc.dat, wateq4f.dat and pitzer.dat. It was found that in the case of low mineralization waters, the results obtained in each of the databases are similar for the minerals present in all the databases. However, in the case of solutions with high mineralization, there are significant differences in the obtained results. The calculated solubility indices allowed to determine the direction of the precipitation/dissolution reaction of individual minerals in the deposit and to indicate the risks, mainly with the formation of iron compounds deposits, for the operation of the injection well. Laboratory tests of water mixing were also carried out. The formation of iron oxide deposits that could damage the near-well zone was observed, which confirmed the results obtained during computer simulations.

Key words: reservoir waters, water injection, solubility index, PHREEQC.

Autor do korespondencji: P. Jakubowicz, e-mail: piotr.jakubowicz@inig.pl

Artykuł nadesłano do Redakcji 18.11.2020 r. Zatwierdzono do druku: 06.04.2021 r. 


\section{Opis problematyki zatłaczania wód złożowych}

Podczas eksploatacji złóż ropy naftowej i gazu ziemnego przeważnie wydobywane są też pewne ilości wody. Stosunek objętości wydobytej wody do objętości wydobytych mediów złożowych zwykle wzrasta wraz z czasem eksploatacji złoża. Wydobyta woda złożowa zawiera zazwyczaj znaczne ładunki zanieczyszczeń szkodliwych dla środowiska i z tego powodu nie może być odprowadzana do wód powierzchniowych i ziemi (Steliga et. al., 2015). Obecnie praktycznie całość wód wydobytych w procesie eksploatacji węglowodorów jest zagospodarowana poprzez zatłoczenie do wyeksploatowanych złóż węglowodorów lub wykorzystana do zwiększenia stopnia sczerpania złoża (nawadnianie złóż) (Muggeridge et al., 2014; Rubinstein i Mahani, 2015; Lubaś et al., 2019).

Skład wód złożowych uzyskiwanych z danego odwiertu ulega dużym zmianom, głównie ze względu na zmiany przepływu i temperatury wydobywanych mediów oraz rodzaju i ilości stosowanych środków chemicznych. Zawartość soli mineralnych w wodzie wydobytej może zmieniać się od wartości występujących w solance złożowej aż do cechujących wodę kondensacyjną, praktycznie pozbawioną rozpuszczonych soli. Ponadto $\mathrm{w}$ wodzie obecne są zanieczyszczenia mechaniczne w postaci unoszonych ze złoża cząstek skalnych i piasku, drobnych cząstek iłów, powodujących tworzenie się trudno sedymentujących zawiesin, pozostałości płuczek wiertniczych, produktów korozji orurowania odwiertu itp.

Występowanie zanieczyszczeń stałych, a także wysoka zmienność składu chemicznego oraz właściwości fizycznych wydobytych wód złożowych powodują poważne trudności w prawidłowym ich zagospodarowaniu. Bezpośrednie zatłoczenie wody do odwiertu chłonnego może skutkować szybkim osadzeniem się cząstek stałych na ścianach odwiertu oraz w strefie przyodwiertowej, powodując ograniczenie przepływu wody. $Z$ tego względu w większości przypadków konieczne jest odpowiednie przygotowanie wód do zatłoczenia. Przeważnie realizowane jest to poprzez sedymentację osadów obecnych $\mathrm{w}$ wodzie realizowaną $\mathrm{w}$ zbiornikach magazynowych oraz filtrację na filtrach piaskowych. W dużej liczbie przypadków taki sposób przygotowania jest dalece niewystarczający, ponieważ duża część zawiesin o małych rozmiarach nie może być odfiltrowana na filtrze piaskowym. Ponadto w kontakcie wody z powietrzem mogą wytrącać się koloidalne zawiesiny tlenków żelaza i manganu, które nieusunięte z zatłaczanej wody głęboko penetrują strefę przyodwiertową, powodując rozległe i trudne do usunięcia uszkodzenia. Rozwiązaniem takiej sytuacji jest zastosowanie instalacji przygotowania wody wykorzystującej odpowiednio dobrane procesy usuwania zanieczyszczeń: usunięcie jonów żelaza i manganu (przez napowietrzenie, w procesie wymiany jonowej czy też zamaskowanie ich obecności związkami kompleksującymi), przeprowadzenie koagulacji (wytrącanie zanieczyszczeń w postaci osadów) z flokulacją (zbrylenie cząstek zawiesin i koloidów), a następnie sedymentacji i/lub filtracji w celu usunięcia cząstek stałych z fazy wodnej (Jakubowicz, 2010; Teh et al., 2016; Jakubowicz i Steliga, 2017; He et al., 2019).

Ze względu na duże zróżnicowanie zawartości poszczególnych składników w wodach złożowych nie ma możliwości jednorazowego ustalenia parametrów poszczególnych procesów oczyszczania. Konieczny jest dobór dawek środków chemicznych i kontrola efektywności procesu indywidualnie dla każdej partii wody przeznaczonej do zatłoczenia (Jakubowicz i Steliga, 2012).

Jednakże nawet prawidłowe i efektywne przeprowadzenie procesu przygotowania wody złożowej może nie ochronić przed postępującą kolmatacją strefy przyodwiertowej. W przypadku zatłaczania do złoża wody o innym składzie chemicznym (obecność składników niekompatybilnych) mogą zachodzić niepożądane procesy chemiczne. Wytrącanie cząstek osadów i zawiesin może zachodzić podczas kontaktu wody zatłaczanej z obecną w złożu wodą rodzimą oraz ze skałą złożową, a także w przypadku zatłoczenia kolejno partii wody o zawartości składników reagujących ze sobą z wytrąceniem osadów. Przebieg reakcji powstawania osadów może być generowany nie tylko przez obecność anionów i kationów tworzących trudno rozpuszczalne związki, ale także poprzez zmianę właściwości fizycznych i chemicznych wody (np. zmiana pH, potencjału redukcyjno-utleniającego, temperatury itp.) (Kluk, 2011). $\mathrm{Z}$ uwagi na wysoki stopień skomplikowania układu woda zatłaczana-woda złożowa-skała złożowa wraz ze wszystkimi czynnikami wpływającymi na zmiany właściwości fizyczno-chemicznych oraz szerokim wachlarzem oddziaływań pomiędzy poszczególnymi składnikami - dysponowanie danymi analitycznymi nie zawsze pozwala na prawidłową interpretację przebiegu procesów i określenie ich wpływu na stabilność układu, a zwłaszcza na przepuszczalność strefy przyodwiertowej i zdolność do magazynowania wody złożowej.

Jedną z możliwości oceny przebiegu procesów podczas zatłaczania wód do złoża jest przeprowadzenie symulacji komputerowych (Dobrzyński, 2006; Ren et al., 2011; Li et al., 2016; Abdelaziz et al., 2019; Gao et al., 2019; Guorui et al., 2019; Li et al., 2020). W chwili obecnej na rynku dostępnych jest kilka specjalistycznych systemów do modelowania hydrogeochemicznego, np. TOUGHREACT, ChemPlugin, PHREEQC, piChem, które mogą być wykorzystywane podczas rozwiązywania zagadnień związanych z chemizmem i reakcyjnością wód, transportem masy i energii, procesami wytrącania minerałów wtórnych, eksploatacji złóż geotermalnych itp. (Jakóbczyk i Kowalczyk, 2011; Lewkiewicz-Małysa i Winid, 2011; Klunk et al., 2015; Fowler et al., 2016; Hu i Mackay, 
2016; Huber et al., 2017; Uliasz-Misiak i Chruszcz-Lipska, 2017; Wanner et al., 2017; Daneshgar et al., 2018). Do testów wybrano program PHREEQC (pH-REdox-EQuilibrium) (Parkhurst i Appelo, 1999; Heredia, 2017; Lassin et al., 2017), który pozwala m.in. na wykonywanie symulacji na silnie stężonych solankach z wykorzystaniem teorii Pitzera.

W celu określenia przydatności programu PHREEQC do przewidywania kierunku przebiegu reakcji rozpuszczania/wytrącania minerałów podczas mieszania się wód złożowych i ich kontaktu ze skałą zbiornikową - przeprowadzono wstępne porównania wyników obliczeń komputerowych wykorzystujących bazy danych zamieszczonych w programie z danymi uzyskanymi z analiz laboratoryjnych.

\section{Metodyka badawcza}

Materiał badawczy stanowiły wody separatorowe z odwiertów eksploatujących złoże w wapieniu cechsztyńskim, o silnie zróżnicowanych właściwościach. W badanych wodach oznaczono: odczyn, potencjał redox i zawartość sodu (miernik $\mathrm{pH} / \mathrm{mV} / \mathrm{Ion} /{ }^{\circ} \mathrm{C} / \mathrm{F}$ - ION 700 błąd pomiaru $2 \%$ ), chemiczne i biologiczne zapotrzebowanie tlenu, ogólny węgiel organiczny, anionowe i niejonowe środki powierzchniowo czynne oraz potas (fotometr Hach Lange DR 3900 - błąd pomiaru 4\%), gęstość (Anton Paar 35N błąd pomiaru 5\%), zawartość substancji rozpuszczonych, nierozpuszczonych, pozostałość po prażeniu w $600^{\circ} \mathrm{C}$ oraz zawartość substancji organicznych (waga analityczna WAA $220 / \mathrm{C} / 2$ - błąd pomiaru 3\%), aniony $\left(\mathrm{Cl}^{-}, \mathrm{Br}^{-}, \mathrm{CO}_{3}{ }^{2-}, \mathrm{HCO}_{3}^{-}, \mathrm{S}^{2-}\right.$, $\mathrm{SO}_{4}{ }^{2-}$ ), wapń i magnez, węglany i wodorowęglany oraz chlorki (miareczkowanie kompleksometryczne, alkacymetryczne i argentometryczne - błąd analizy 4\%), siarczany, żelazo, mangan i wybrane
Tabela 1. Wyniki analiz fizyczno-chemicznych próbek wody z utworzonych strumieni zbiorczych

Table 1. Results of physico-chemical analyses of water samples from cumulative streams

\begin{tabular}{|c|c|c|c|c|c|}
\hline \multirow{2}{*}{ Oznaczenie } & \multirow{2}{*}{ Jednostka } & \multicolumn{4}{|c|}{ Strumienie wody separatorowej } \\
\hline & & S1K & $\mathbf{S} 2 \mathbf{K}$ & S3K & S4K \\
\hline $\mathrm{pH}$ & & 5,3 & 4,8 & 4,1 & 5,9 \\
\hline $\mathrm{Eh}$ & $\mathrm{mV}$ & $-17,2$ & $-117,8$ & -37 & -108 \\
\hline Gęstość $\left(20^{\circ} \mathrm{C}\right)$ & $\mathrm{g} / \mathrm{cm}^{3}$ & 0,998 & 1,182 & 0,895 & 0,997 \\
\hline Sucha pozostałość & $\mathrm{mg} / \mathrm{dm}^{3}$ & 575 & 306428 & 79858 & 551 \\
\hline Pozostałość po prażeniu & $\mathrm{mg} / \mathrm{dm}^{3}$ & 361 & 288904 & 60352 & 318 \\
\hline Zawiesina ogólna & $\mathrm{mg} / \mathrm{dm}^{3}$ & 75,2 & 159 & 109,4 & 76 \\
\hline $\mathrm{ChZT}_{(\mathrm{Cr})}$ & $\mathrm{mg} \mathrm{O} / \mathrm{dm}^{3}$ & 16239 & 13589 & 18425 & 15023 \\
\hline $\mathrm{BZT}_{5}$ & $\mathrm{mg} \mathrm{O} / \mathrm{dm}^{3}$ & 3072 & 2258 & 2322 & 1875 \\
\hline OWO & $\mathrm{mg} / \mathrm{dm}^{3}$ & 2632 & 1059 & 1623 & 1004 \\
\hline TPH & $\mathrm{mg} / \mathrm{dm}^{3}$ & 178 & 284 & 76 & 64 \\
\hline $\begin{array}{l}\text { Substancje organiczne } \\
\text { (ekstrakt dichlorometanem) }\end{array}$ & $\mathrm{mg} / \mathrm{dm}^{3}$ & 552 & 1102 & 154 & 91 \\
\hline SPCz anionowe & $\mathrm{mg} / \mathrm{dm}^{3}$ & 0,19 & 18,9 & 6,88 & 1,23 \\
\hline SPCz niejonowe & $\mathrm{mg} / \mathrm{dm}^{3}$ & 228 & 1,73 & 165 & 247 \\
\hline $\mathrm{Cl}^{-}$ & $\mathrm{mg} / \mathrm{dm}^{3}$ & 77,3 & 176615 & 39135 & 129 \\
\hline $\mathrm{SO}_{4}{ }^{2-}$ & $\mathrm{mg} / \mathrm{dm}^{3}$ & 9,4 & 189 & 45,8 & 4,3 \\
\hline $\mathrm{CO}_{3}{ }^{2-}$ & $\mathrm{mg} / \mathrm{dm}^{3}$ & n.s. & n.s. & n.s. & n.s. \\
\hline $\mathrm{HCO}_{3}^{-}$ & $\mathrm{mg} / \mathrm{dm}^{3}$ & 217 & 169 & 212 & 215 \\
\hline $\mathrm{Br}^{-}$ & $\mathrm{mg} / \mathrm{dm}^{3}$ & n.s. & 249,3 & 54,41 & 4,12 \\
\hline $\mathrm{Na}^{+}$ & $\mathrm{mg} / \mathrm{dm}^{3}$ & 98,558 & 68841 & 15114 & 61,9 \\
\hline $\mathrm{K}^{+}$ & $\mathrm{mg} / \mathrm{dm}^{3}$ & 22,258 & 588 & 448 & 28,6 \\
\hline $\mathrm{Ca}^{2+}$ & $\mathrm{mg} / \mathrm{dm}^{3}$ & 2,989 & 35258 & 8039 & 18,6 \\
\hline $\mathrm{Mg}^{2+}$ & $\mathrm{mg} / \mathrm{dm}^{3}$ & 0,645 & 4974 & 969 & 12,7 \\
\hline $\mathrm{Fe}^{2+}$ & $\mathrm{mg} / \mathrm{dm}^{3}$ & 7,42 & 6,50 & 3,72 & 2,10 \\
\hline $\mathrm{Fe}^{3+}$ & $\mathrm{mg} / \mathrm{dm}^{3}$ & 13,06 & 56,40 & 37,35 & 16,00 \\
\hline $\mathrm{Mn}^{2+}$ & $\mathrm{mg} / \mathrm{dm}^{3}$ & 4,18 & 7,05 & 5,12 & 3,91 \\
\hline $\mathrm{Cu}$ & $\mathrm{mg} / \mathrm{dm}^{3}$ & 0,022 & 0,009 & 0,019 & 0,021 \\
\hline $\mathrm{Pb}$ & $\mathrm{mg} / \mathrm{dm}^{3}$ & 0,073 & 0,035 & 0,051 & 0,068 \\
\hline $\mathrm{Zn}$ & $\mathrm{mg} / \mathrm{dm}^{3}$ & 0,027 & 0,358 & 0,364 & 0,651 \\
\hline $\mathrm{Sn}$ & $\mathrm{mg} / \mathrm{dm}^{3}$ & 0,014 & 0,51 & 0,011 & 0,023 \\
\hline $\mathrm{Ni}$ & $\mathrm{mg} / \mathrm{dm}^{3}$ & 0,031 & 0,129 & 0,067 & 0,067 \\
\hline Co & $\mathrm{mg} / \mathrm{dm}^{3}$ & 0,004 & 0,028 & 0,009 & 0,009 \\
\hline $\mathrm{Cd}$ & $\mathrm{mg} / \mathrm{dm}^{3}$ & 0,006 & 0,048 & 0,007 & 0,003 \\
\hline $\mathrm{Sr}$ & $\mathrm{mg} / \mathrm{dm}^{3}$ & 0,019 & 3012 & 0,052 & 0,061 \\
\hline $\mathrm{Ba}$ & $\mathrm{mg} / \mathrm{dm}^{3}$ & 0,029 & 81 & 0,026 & 0,038 \\
\hline $\mathrm{Si}$ & $\mathrm{mg} / \mathrm{dm}^{3}$ & 4,925 & 4,26 & 7,98 & 3,18 \\
\hline $\mathrm{Al}$ & $\mathrm{mg} / \mathrm{dm}^{3}$ & 0,011 & 0,056 & 0,049 & 0,061 \\
\hline
\end{tabular}

metale ciężkie (spektrofotometr UV/VIS Lambda 35 - błąd pomiaru $4 \%$ ).

Analizy laboratoryjne zostały uzupełnione przez analizę mineralogiczną próbek materiału rdzeniowego $\mathrm{z}$ odwiertu przeznaczonego do zatłaczania. Ilościową analizę składu mineralnego próbek rdzeni wykonano metodą dyfrakcji 
rentgenowskiej (XRD) w Zakładzie Geofizyki Wiertniczej INiG - PIB (Cebulski et al., 2017). Pomiary ilościowe wykonane zostały na aparacie X'Pert Pro firmy Panalytical wyposażonym w nowoczesny licznik paskowy X'Celerator.

\section{Wyniki badań laboratoryjnych}

Przeprowadzone analizy fizyczno-chemiczne pozwoliły na ustalenie składu wód (tab. 1). Dwie próbki stanowiły wody kondensacyjne o zbliżonych zawartościach zawiesin i bardzo niskiej mineralizacji: S1K $\left(575 \mathrm{mg} / \mathrm{dm}^{3}\right)$ - próbka zmieszana w równych proporcjach z trzech próbek wód separatorowych o podobnych właściwościach i próbka S4K $\left(551 \mathrm{mg} / \mathrm{dm}^{3}\right)$ z separatora odwiertu eksploatacyjnego. Następną próbkę (S2K) stanowiła woda o wysokiej mineralizacji $\left(306428 \mathrm{mg} / \mathrm{dm}^{3}\right)$ i najwyższej zawartości zawiesin $\left(159 \mathrm{mg} / \mathrm{dm}^{3}\right)$. Ostatnią próbką (S3K), o średniej zawartości substancji rozpuszczonych
(79 $\left.858 \mathrm{mg} / \mathrm{dm}^{3}\right)$ i zawiesin $\left(109,4 \mathrm{mg} / \mathrm{dm}^{3}\right)$, była woda zbiorcza sporządzona przez zmieszanie w różnych proporcjach wody separatorowej z 9 otworów eksploatacyjnych.

W celu stwierdzenia, czy podczas mieszania się wód separatorowych nie powstają osady wtórne, przeprowadzono badania podczas sporządzania próbek wody S1K i S3K. Ze względu na znaczny udział zawiesin w wodach składowych badania przeprowadzono na próbkach przefiltrowanych przez sączek $0,22 \mu \mathrm{m}$. Odnotowano powstawanie osadów barwy czerwono-brunatnej, co - jak wykazały analizy - spowodowane było wytrąceniem się tlenków i wodorotlenków żelaza w kontakcie z powietrzem. Podobnie zachowywały się próbki pozostałych wód separatorowych (rys. 1, tab. 2). W przypadku żadnej z badanych wód nie stwierdzono powstawania innych osadów niż tlenki żelaza.

W celu ustalenia składu skały złożowej wykonano analizę mineralogiczną materiału rdzeniowego pochodzącego z otworu zatłaczającego (rys. 2). Analiza wykazała, że głównym
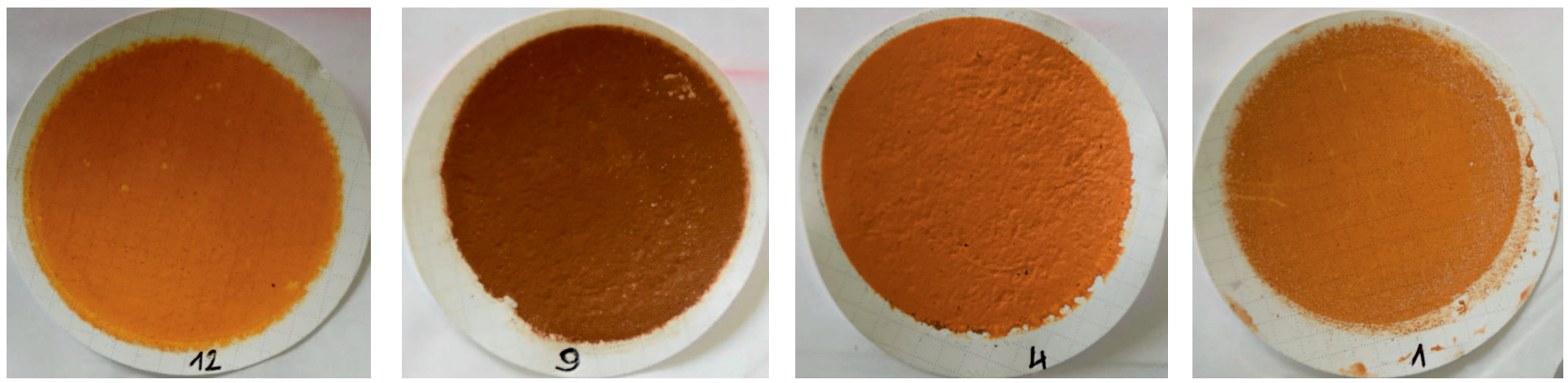

Rys. 1. Osady uzyskane po przefiltrowaniu próbek wód separatorowych

Fig. 1. Sediments obtained after filtering the separator water samples

Tabela 2. Analiza grawimetryczna osadów wytrąconych z wód separatorowych

Table 2. Gravimetric analysis of sediments precipitated from separator waters

\begin{tabular}{|c|c|c|c|c|}
\hline \multirow{2}{*}{ Analiza } & \multicolumn{4}{|c|}{ Próbka wody separatorowej } \\
\cline { 2 - 5 } & S1K & S2K & S3K & S4K \\
\hline \hline Masa osadu $\left[\mathrm{mg} / \mathrm{dm}^{3}\right]$ & 16,50 & 55,40 & 48,61 & 14,35 \\
\hline
\end{tabular}

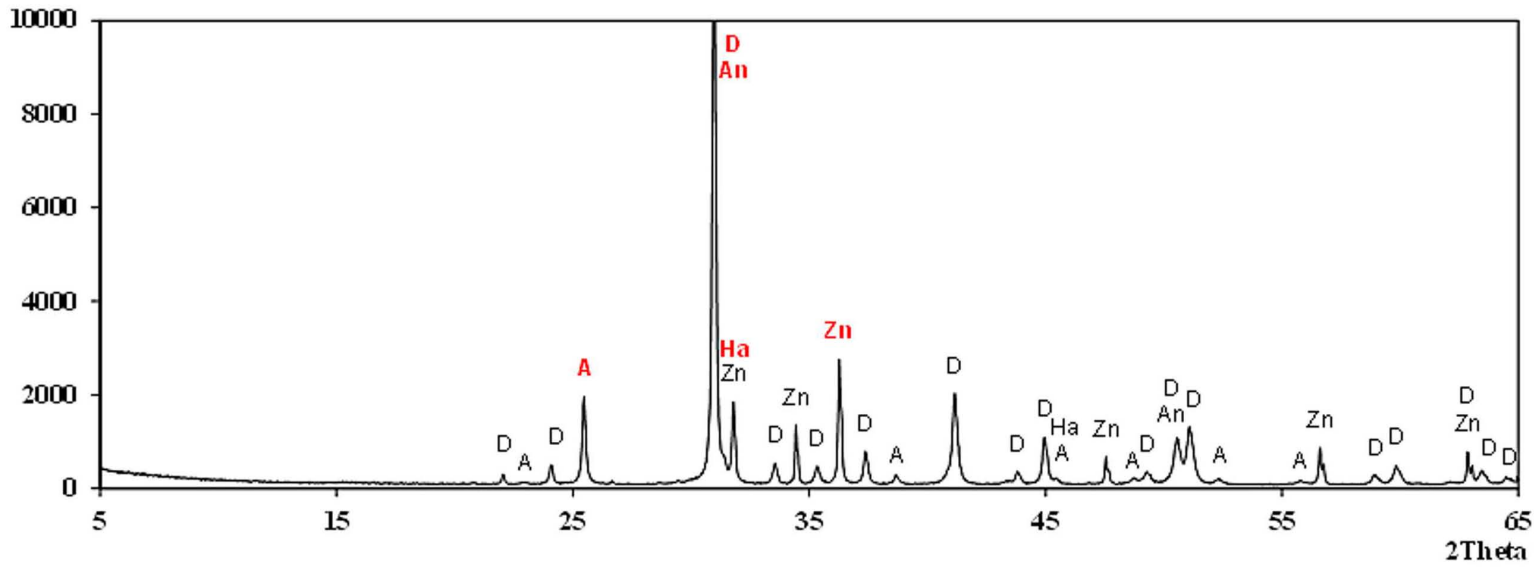

Rys. 2. Wyniki analizy składu mineralnego materiału rdzeniowego z odwiertu zatłaczającego

Fig. 2. The results of the mineral composition analysis of the core material from the injection well 
składnikiem skał zbiornikowych jest dolomit (74,6\%), w mniejszych ilościach występują anhydryt $(13,1 \%)$ i ankeryt $(11,3 \%)$ - węglan wapnia i żelaza o wzorze $\mathrm{CaFe}\left(\mathrm{CO}_{3}\right)_{2}$ oraz niewielki dodatek halitu (1,0\%).

Uzyskane wyniki analiz i badań laboratoryjnych wskazują, że samo usunięcie osadów i zawiesin z fazy wodnej nie wystarczy do bezpiecznego zatłaczania wody do horyzontu chłonnego. Ze względu na obecność jonów żelaza, które stosunkowo łatwo ulegają utlenieniu i zostają wytrącone w postaci osadów, w przypadku podwyższenia potencjału elektrochemicznego wody separatorowej może następować kolmatacja strefy przyodwiertowej w trakcie zatłaczania. Podwyższenie Eh może nastąpić nie tylko poprzez kontakt z powietrzem, ale także przez samo odgazowanie wody z rozpuszczonych w niej pod wysokim ciśnieniem węglowodorów (metanu), a także przez zmieszanie z wodą o charakterze utleniającym.

\section{Obliczenia indeksów rozpuszczalności w programie PHREEQC}

Jednym ze wskaźników sugerujących możliwy przebieg reakcji rozpuszczania/wytrącania minerałów podczas mieszania się wód lub w kontakcie wody ze skałą złożową jest indeks rozpuszczalności (SI - ang. solubility index). W związku z wykorzystywaniem tych informacji podczas rozpatrywania procesu mieszania wód separatorowych i ich zatłaczania do horyzontu chłonnego - szczególną uwagę zwrócono na możliwości programu PHREEQC w zakresie obliczania wartości SI (Parkhurst i Appelo, 1999).

W programie funkcjonują trzy bazy danych, na których mogą zostać oparte obliczenia indeksów rozpuszczalności: phreeqc.dat (Parkhurst et al., 1980), pitzer.dat (Pitzer, 1973; Plummer et al., 1988) i wateq4f.dat (Ball and Nordstrom, 1991). $\mathrm{Z}$ doniesień literaturowych wynika, że do symulacji silnie stężonych solanek powinna być stosowana baza pitzer.dat, która opiera się na obliczaniu siły jonowej roztworu (teoria Pitzera), a nie stężeń składników. Pozostałe dwie bazy powinny być wykorzystywane do obliczeń w roztworach znajdujących się w obszarze Debye'a-Hückla (niskie stężenia).

Bazy danych dostarczone z programem PHREEQC różnią się liczbą minerałów, dla których mogą zostać wykonane obliczenia, a także uzyskiwanymi wynikami. Najmniejszą bazą danych, obejmującą około 40 minerałów i związków chemicznych, jest pitzer.dat. Większą bazę stanowi phreeqc.dat, z wprowadzonymi danymi dotyczącymi około 60 minerałów, natomiast baza wateq4f.dat obejmuje ponad 300 pozycji.

Składy wód uzyskane w analizach laboratoryjnych posłużyły jako podstawa do wykonania obliczeń indeksów nasycenia dla poszczególnych minerałów. Rozpatrując uzyskane wartości indeksów nasycenia (SI) obliczone przy wykorzystaniu bazy phreeqc.dat, można zauważyć, że potencjał rozpuszczania/wytrącania poszczególnych minerałów jest bardzo zróżnicowany (rys. 3). W przypadku większości substancji równowaga $\mathrm{w}$ roztworach wód separatorowych jest przesunięta w kierunku rozpuszczania. W kierunku wytrącania (w układzie istnieje stan przesycenia) równowaga przesunięta jest głównie w przypadku minerałów zawierających żelazo (goetyt, hematyt, piryt) oraz glinokrzemianów (montmorylonit, mika, kaolinit). Natomiast związki manganu, zwykle wskazywane wraz z żelazem jako produkt łatwo wytrącający się z roztworu w postaci osadów tlenków i wodorotlenków, wykazują równowagę przesuniętą w kierunku rozpuszczania (wysokie ujemne wartości SI).

Drugą bazą danych zastosowaną do obliczeń równowagowych dla wód separatorowych była baza pitzer.dat. Praktycznie wszystkie uwzględniane w obliczeniach minerały znajdują się w stanie niedosycenia $\mathrm{w}$ roztworze $\mathrm{i}$ ich równowaga przesunięta jest w kierunku rozpuszczania (tab. 3). Jedynie w przypadku stężonej solanki S2K (dla aragonitu, kalcytu, celestynu i dolomitu) oraz wody ze strumienia S3K (dla kalcytu) stwierdzono nieznaczne przesunięcie równowagi w kierunku wytrącania osadów. Ze względu na brak minerałów zawierających żelazo wykorzystanie tej bazy do modelowania procesów zachodzących podczas zatłaczania wód separatorowych do złoża jest znacznie ograniczone.

Zastosowanie bazy wateq4f.dat pozwala na uzyskanie największej ilości informacji dotyczących różnych minerałów i stanu równowagi badanej fazy wodnej. Informacje otrzymane z wykorzystaniem tej bazy danych są dość zbliżone do przypadku bazy phreeqc.dat. Odnotowano, że stan równowagi woda-składniki mineralne dla badanych układów jest przeważnie przesunięty w kierunku rozpuszczania minerałów, czyli nienasycenia fazy wodnej ich składnikami. Obliczenia wykazały, że w przypadku wszystkich analizowanych strumieni wód należy się spodziewać wytrącania minerałów zawierających żelazo (hematyt, goetyt, magnetyt i inne związki żelaza), a także barytu i kwarcu.

\section{Porównanie wyników obliczeń i analiz laboratoryjnych}

Dokonano porównań indeksów rozpuszczalności dla głównych strumieni wód separatorowych obliczonych z wykorzystaniem baz danych phreeqc.dat, pitzer.dat i wateq4f.dat. Porównując wyniki uzyskane dla bazy phreeqc.dat i wateq4.dat, można stwierdzić, że dla wód o niskiej zawartości substancji rozpuszczonych (S1K i S4K) otrzymano identyczne wartości SI. W przypadku wody o większym zasoleniu (S3K), a zwłaszcza S2K (mineralizacja na poziomie $300000 \mathrm{mg} / \mathrm{dm}^{3}$ ), 


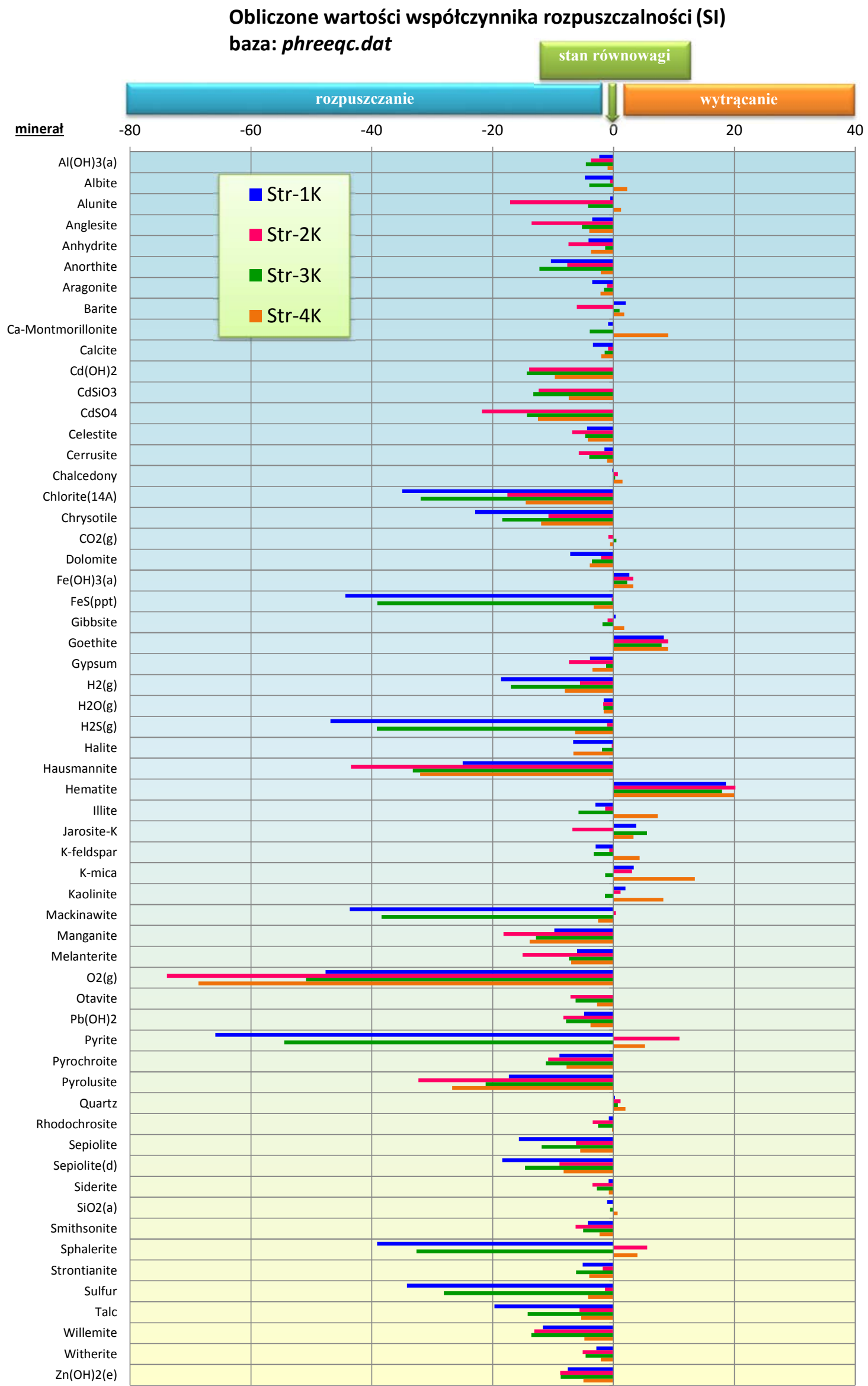

Rys. 3. Porównanie indeksów rozpuszczalności obliczonych dla poszczególnych wód separatorowych z wykorzystaniem bazy danych phreeqc.dat

Fig. 3. Comparison of the solubility indexes calculated for individual separator waters using the phreeqc.dat database 
Tabela 3. Indeksy nasycenia obliczone w programie PHREEQC z wykorzystaniem bazy danych pitzer.dat dla poszczególnych wód separatorowych

Table 3. Saturation indexes calculated with the PHREEQC using the pitzer.dat database for individual separator waters

\begin{tabular}{|c|c|c|c|c|c|}
\hline \multirow{2}{*}{ Mineral } & \multirow{2}{*}{ Wzór chemiczny } & \multicolumn{4}{|c|}{ Indeks nasycenia } \\
\hline & & S1K & S2K & S3K & S4K \\
\hline Anhydrite & $\mathrm{CaSO}_{4}$ & $-4,04$ & $-0,22$ & $-1,19$ & $-3,70$ \\
\hline Aragonite & $\mathrm{CaCO}_{3}$ & $-3,19$ & 0,36 & $-0,07$ & $-2,28$ \\
\hline Arcanite & $\mathrm{K}_{2} \mathrm{SO}_{4}$ & $-8,91$ & $-6,91$ & $-6,71$ & $-9,04$ \\
\hline Bischofite & $\mathrm{MgCl}_{2} \cdot 6 \mathrm{H}_{2} \mathrm{O}$ & $-14,69$ & $-3,93$ & $-5,76$ & $-12,87$ \\
\hline Bloedite & $\mathrm{Na}_{2} \mathrm{Mg}\left(\mathrm{SO}_{4}\right)_{2} \cdot 4 \mathrm{H}_{2} \mathrm{O}$ & $-15,44$ & $-6,59$ & $-8,51$ & $-15,39$ \\
\hline Brucite & $\mathrm{Mg}(\mathrm{OH})_{2}$ & $-10,69$ & $-7,87$ & $-7,93$ & $-9,03$ \\
\hline Burkeite & $\mathrm{Na}_{6} \mathrm{CO}_{3}\left(\mathrm{SO}_{4}\right)_{2}$ & $-29,13$ & $-13,00$ & $-15,80$ & $-30,94$ \\
\hline Calcite & $\mathrm{CaCO}_{3}$ & $-3,00$ & 0,55 & 0,12 & $-2,09$ \\
\hline Carnallite & $\mathrm{KMgCl}_{3} \cdot 6 \mathrm{H}_{2} \mathrm{O}$ & $-20,62$ & $-5,06$ & $-7,40$ & $-18,38$ \\
\hline Celestite & $\mathrm{SrSO}_{4}$ & $-4,35$ & 0,49 & $-0,88$ & $-4,23$ \\
\hline $\mathrm{CO}_{2}(\mathrm{~g})$ & $\mathrm{CO}_{2}$ & $-0,38$ & 0,27 & $-0,18$ & $-0,62$ \\
\hline Dolomite & $\mathrm{CaMg}\left(\mathrm{CO}_{3}\right)_{2}$ & $-6,25$ & 0,88 & $-0,13$ & $-3,92$ \\
\hline Epsomite & $\mathrm{MgSO}_{4} \cdot 7 \mathrm{H}_{2} \mathrm{O}$ & $-6,89$ & $-3,84$ & $-4,41$ & $-6,04$ \\
\hline Gaylussite & $\mathrm{CaNa}_{2}\left(\mathrm{CO}_{3}\right)_{2} \cdot 5 \mathrm{H}_{2} \mathrm{O}$ & $-13,94$ & $-5,76$ & $-6,35$ & $-13,24$ \\
\hline Glaserite & $\mathrm{NaK}_{3}\left(\mathrm{SO}_{4}\right)_{2}$ & $-16,83$ & $-11,09$ & $-11,35$ & $-17,41$ \\
\hline Glauberite & $\mathrm{Na}_{2} \mathrm{Ca}\left(\mathrm{SO}_{4}\right)_{2}$ & $-12,09$ & $-2,81$ & $-4,89$ & $-12,54$ \\
\hline Gypsum & $\mathrm{CaSO}_{4} \cdot 2 \mathrm{H}_{2} \mathrm{O}$ & $-3,79$ & $-0,20$ & $-1,01$ & $-3,45$ \\
\hline $\mathrm{H}_{2} \mathrm{O}(\mathrm{g})$ & $\mathrm{H}_{2} \mathrm{O}$ & $-1,64$ & $-1,76$ & $-1,68$ & $-1,64$ \\
\hline Halite & $\mathrm{NaCl}$ & $-6,74$ & $-0,20$ & $-1,36$ & $-6,65$ \\
\hline Hexahydrite & $\mathrm{MgSO}_{4} \cdot 6 \mathrm{H}_{2} \mathrm{O}$ & $-7,14$ & $-3,98$ & $-4,62$ & $-6,29$ \\
\hline Kainite & $\mathrm{KMgClSO}_{4} \cdot 3 \mathrm{H}_{2} \mathrm{O}$ & $-14,71$ & $-6,41$ & $-7,79$ & $-13,44$ \\
\hline Kalicinite & $\mathrm{KHCO}_{3}$ & $-6,10$ & $-4,96$ & $-4,78$ & $-6,00$ \\
\hline Kieserite & $\mathrm{MgSO}_{4} \cdot \mathrm{H}_{2} \mathrm{O}$ & $-8,70$ & $-4,98$ & $-6,02$ & $-7,86$ \\
\hline Labile_S & $\mathrm{Na}_{4} \mathrm{Ca}\left(\mathrm{SO}_{4}\right)_{3} \cdot 2 \mathrm{H}_{2} \mathrm{O}$ & $-20,62$ & $-6,11$ & $-9,15$ & $-21,87$ \\
\hline Leonhardite & $\mathrm{MgSO}_{4} \cdot 4 \mathrm{H}_{2} \mathrm{O}$ & $-7,94$ & $-4,55$ & $-5,36$ & $-7,10$ \\
\hline Leonite & $\mathrm{K}_{2} \mathrm{Mg}\left(\mathrm{SO}_{4}\right)_{2} \cdot 4 \mathrm{H}_{2} \mathrm{O}$ & $-15,61$ & $-10,22$ & $-10,83$ & $-14,89$ \\
\hline Magnesite & $\mathrm{MgCO}_{3}$ & $-4,02$ & $-0,44$ & $-1,02$ & $-2,60$ \\
\hline Mirabilite & $\mathrm{Na}_{2} \mathrm{SO}_{4} \cdot 10 \mathrm{H}_{2} \mathrm{O}$ & $-7,52$ & $-3,20$ & $-3,51$ & $-8,31$ \\
\hline Misenite & $\mathrm{K}_{8} \mathrm{H}_{6}\left(\mathrm{SO}_{4}\right)_{7}$ & $-78,83$ & $-68,43$ & $-70,38$ & $-81,78$ \\
\hline Nahcolite & $\mathrm{NaHCO}_{3}$ & $-4,51$ & $-1,65$ & $-2,12$ & $-4,75$ \\
\hline Natron & $\mathrm{Na}_{2} \mathrm{CO}_{3} \cdot 10 \mathrm{H}_{2} \mathrm{O}$ & $-11,15$ & $-7,10$ & $-6,87$ & $-11,37$ \\
\hline Nesquehonite & $\mathrm{MgCO}_{3} \cdot 3 \mathrm{H}_{2} \mathrm{O}$ & $-6,67$ & $-3,44$ & $-3,78$ & $-5,25$ \\
\hline Pentahydrite & $\mathrm{MgSO}_{4} \cdot 5 \mathrm{H}_{2} \mathrm{O}$ & $-7,54$ & $-4,27$ & $-5,00$ & $-6,70$ \\
\hline Pirssonite & $\mathrm{Na}_{2} \mathrm{Ca}\left(\mathrm{CO}_{3}\right)_{2} \cdot 2 \mathrm{H}_{2} \mathrm{O}$ & $-14,12$ & $-5,60$ & $-6,43$ & $-13,43$ \\
\hline Polyhalite & $\mathrm{K}_{2} \mathrm{MgCa}_{2}\left(\mathrm{SO}_{4}\right)_{4} \cdot 2 \mathrm{H}_{2} \mathrm{O}$ & $-22,58$ & $-9,34$ & $-12,05$ & $-21,18$ \\
\hline Portlandite & $\mathrm{Ca}(\mathrm{OH})_{2}$ & $-15,98$ & $-13,19$ & $-13,09$ & $-14,83$ \\
\hline Schoenite & $\mathrm{K}_{2} \mathrm{Mg}\left(\mathrm{SO}_{4}\right)_{2} \cdot 6 \mathrm{H}_{2} \mathrm{O}$ & $-15,26$ & $-10,10$ & $-10,55$ & $-14,55$ \\
\hline Sylvite & $\mathrm{KCl}$ & $-6,92$ & $-2,12$ & $-2,62$ & $-6,50$ \\
\hline Syngenite & $\mathrm{K}_{2} \mathrm{Ca}\left(\mathrm{SO}_{4}\right)_{2} \cdot \mathrm{H}_{2} \mathrm{O}$ & $-11,69$ & $-5,98$ & $-6,68$ & $-11,47$ \\
\hline Trona & $\mathrm{Na}_{3} \mathrm{H}\left(\mathrm{CO}_{3}\right)_{2} \cdot 2 \mathrm{H}_{2} \mathrm{O}$ & $-15,85$ & $-8,01$ & $-8,89$ & $-16,30$ \\
\hline
\end{tabular}

uwidaczniają się pewne niewielkie różnice w obliczonych wartościach SI. Im wyższe zasolenie, tym można zauważyć większe różnice w obliczonych wartościach SI dla niektórych minerałów (rys. 4). Jest to szczególnie dobrze widoczne na przykładzie jarozytu i barytu. W przypadku obu minerałów baza phreeqc.dat wykazuje nienasycenie roztworu i sugeruje rozpuszczanie tych minerałów, natomiast wateq 4 f.dat wskazuje w tych przypadkach przesycenie roztworu i wytrącanie minerałów.

Porównując wskazania baz danych wateq4f.dat i pitzer.dat, można zauważyć większe zróżnicowanie w wartościach SI, wynikające z odmiennych sposobów wykonywania obliczeń. W przypadku wód o niskiej mineralizacji (prawo Debye'aHückla) różnice wydają się mało znaczące i można przyjąć, że dla testowanych układów wód wszystkie bazy danych wskazują bardzo zbliżone wartości.

Natomiast podczas rozpatrywania przypadków bardziej stężonych solanek (rys. 5) uwidacznia się wpływ różnic w wykorzystywanych teoriach opisujących oddziaływania poszczególnych składników roztworów. Zastosowanie w obliczeniach siły jonowej (pitzer.dat) nie oznacza przesunięcia uzyskiwanych wyników tylko w jednym kierunku. W zależności od rozpatrywanego związku i parametrów fizyczno-chemicznych wód wyniki wykazują pewne, przeważnie niewielkie, zróżnicowanie.

Podczas interpretacji wyników należy zwracać szczególną uwagę na zachowanie się poszczególnych składników w newralgicznej strefie zbliżonej do stanu równowagi ( $\mathrm{SI} \approx 0$ ). W tym obszarze nawet niewielka różnica wartości SI może być przyczyną zmiany właściwości roztworu i powodować powstawanie osadów przyspieszających uszkodzenie przepuszczalności skał zbiornikowych.

$\mathrm{Na}$ wykresach zamieszczonych na rys. 6 przedstawiono porównanie wartości indeksów rozpuszczalności obliczonych dla składników uwzględnionych we 
wszystkich trzech bazach danych wykorzystywanych w programie PHREEQC. Dane potwierdzają dość dobrą zbieżność wyników obliczeń dla wód o niskich zawartościach rozpuszczonych soli, natomiast $\mathrm{w}$ przypadku wyższych stężeń solanek (zwłaszcza dla S2K) uwidaczniają się znaczące - dla przewidywania kierunku przebiegu reakcji chemicznych - różnice wartości SI. Zaobserwowane różnice zostały spowodowane zastosowaniem do wykonania obliczeń w porównywanych bazach danych różnych teorii opisujących zachowanie się jonów, a zwłaszcza wykorzystaniem w bazie pitzer.dat siły jonowej roztworu, a nie stężeń poszczególnych składników.

Porównując wyniki symulacji z przeprowadzonymi badaniami laboratoryjnymi mieszania wód, można zauważyć pewne korelacje. W obu przypadkach wyniki wykazały wytrącanie się trudno rozpuszczalnych związków żelaza. Natomiast zarówno badania laboratoryjne, jak i w obliczenia komputerowe nie wskazują na powstawanie innych osadów mogących uszkadzać strefę przyodwiertową. Co prawda obliczenia sugerują możliwość wytrącania się węglanów i siarczanów, ale indeksy świadczą o niewielkiej intensywności procesu, a biorąc pod uwagę niskie zawartości tych składników w wodach, możliwe jest, że nie zostały one wykryte w uzyskanych osadach zastosowanymi technikami analitycznymi.

Należy zauważyć, że wykorzystane bazy danych (z wyjątkiem pitzer.dat) wskazują na silne własności absorpcji tlenu. Zostało to w pełni potwierdzone w badaniach laboratoryjnych,
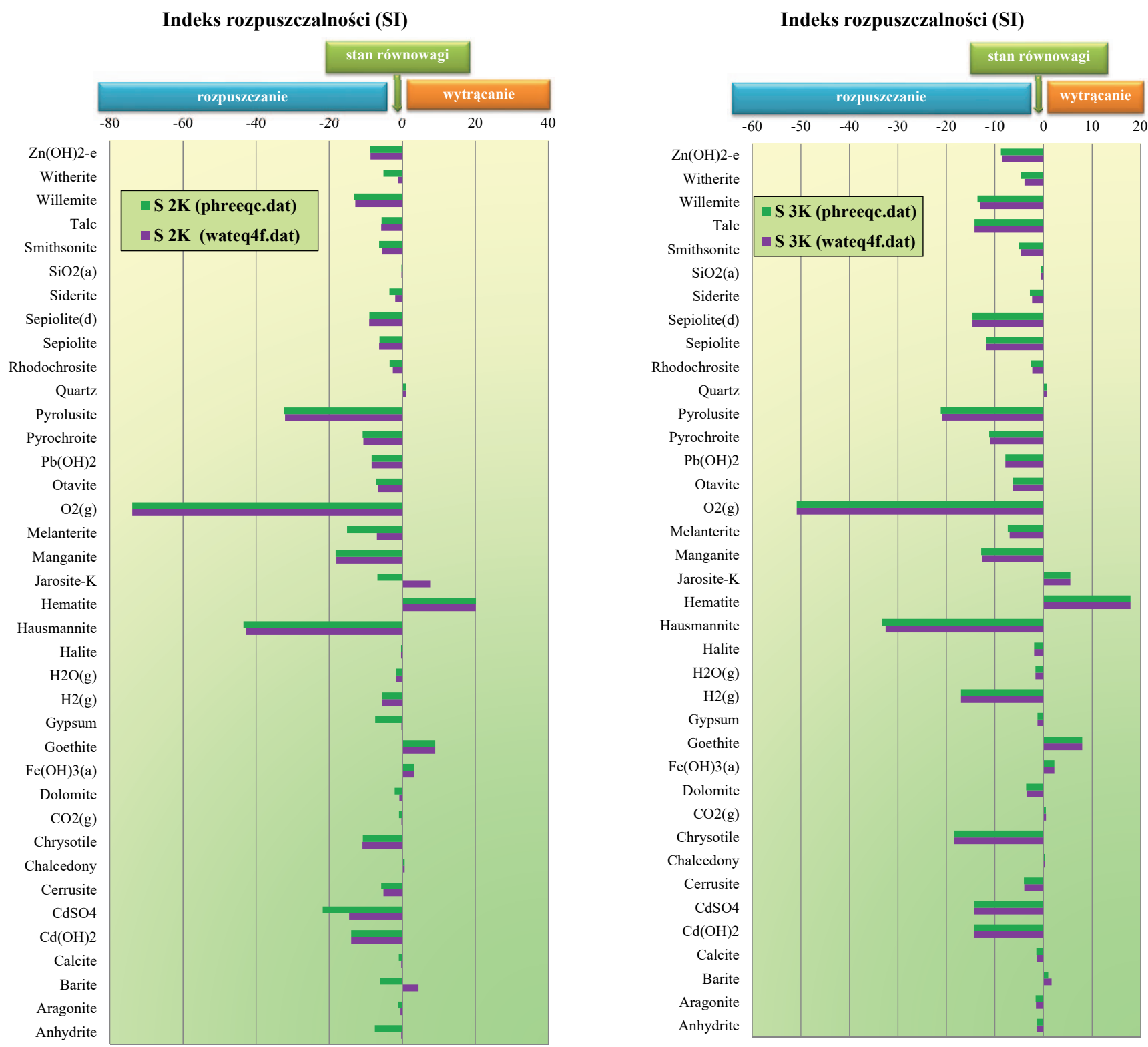

Rys. 4. Porównanie indeksów rozpuszczalności obliczonych z wykorzystaniem bazy phreeqc.dat i wateq4f.dat dla wód o wysokiej (S2K) i średniej (S3K) mineralizacji

Fig. 4. Comparison of the solubility indexes calculated with the use of phreeqc.dat and wateq4f.dat for waters with high (S2K) and medium (S3K) mineralization 

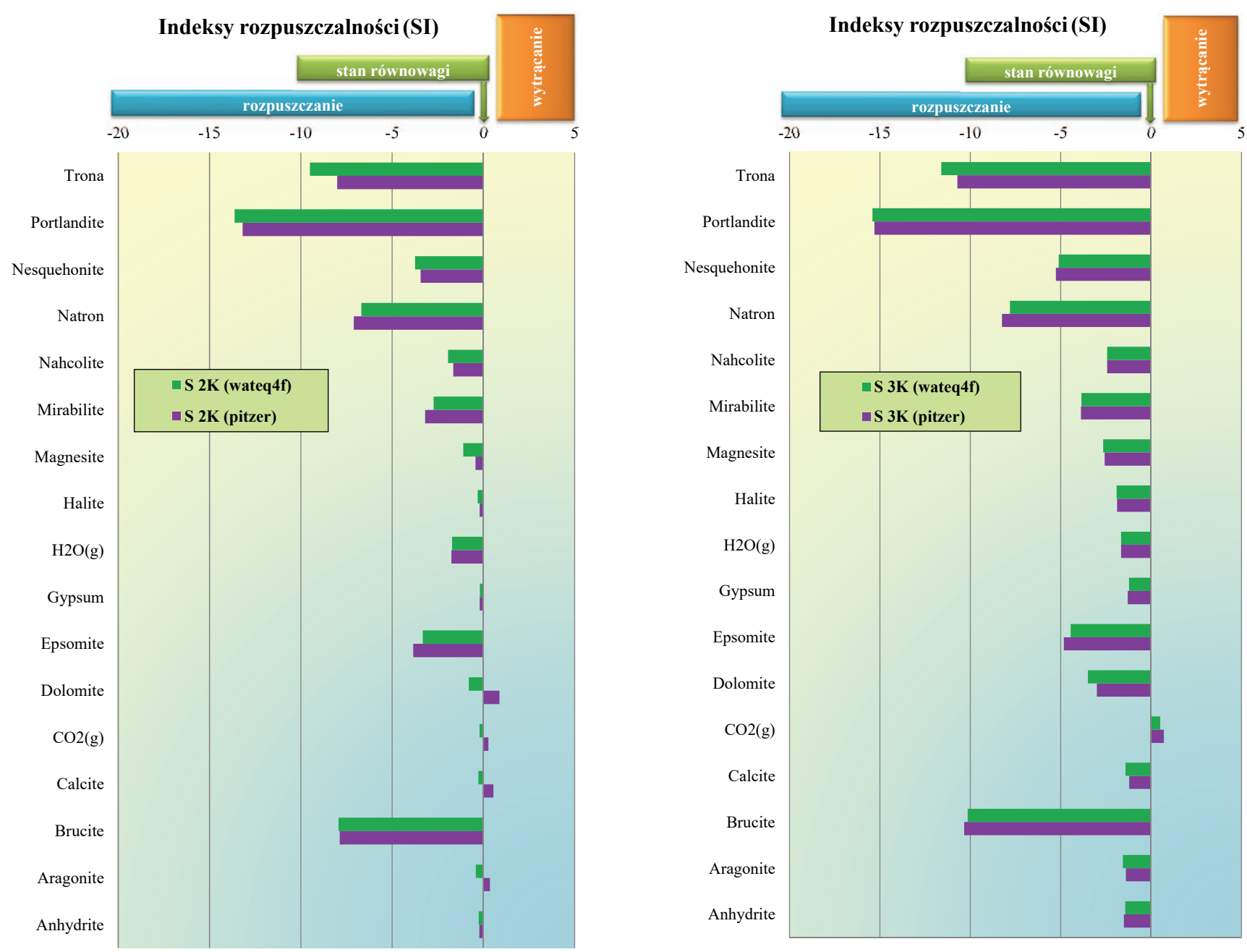

Rys. 5. Porównanie indeksów rozpuszczalności obliczonych z wykorzystaniem bazy pitzer.dat i wateq4f.dat dla wód o wysokiej (S2K) i średniej (S3K) mineralizacji

Fig. 5. Comparison of the solubility indexes calculated using the pitzer.dat and wateq4f.dat databases for waters with high (S2K) and medium (S3K) mineralization

które wykazały duży wzrost własności utleniających wód w kontakcie z powietrzem, a także wytrącanie się tlenków i wodorotlenków żelaza, spowodowane utlenieniem jonów $\mathrm{Fe}^{3+}$ i Fe ${ }^{2+}$ obecnych w wodzie.

\section{Podsumowanie}

Program PHREEQC został przetestowany pod kątem podstawowego zakresu funkcjonalności, jakim jest obliczanie indeksów rozpuszczalności, sugerujących kierunek przebiegu reakcji wytrącania/rozpuszczania poszczególnych minerałów i substancji podczas procesu mieszania wód. W obliczeniach wykorzystano wyniki uzyskane przy zastosowaniu trzech baz danych dostarczanych razem z programem: phreeqc.dat, wateq4f.dat oraz pitzer.dat. Przeprowadzone porównanie pozwoliło na stwierdzenie, że w przypadku wód o niskiej mineralizacji (niskie stężenia składników rozpuszczonych) wyniki uzyskane na podstawie każdej z baz danych są zbliżone dla minerałów występujących we wszystkich bazach. Natomiast w przypadku roztworów o wysokiej mineralizacji pojawiają się różnice $\mathrm{w}$ wynikach otrzymanych przy wykorzystaniu każdej z baz danych. Różnice te dotyczą zarówno wartości obliczanego SI, jak i sugerowanego kierunku przebiegu reakcji (rozpuszczanie lub wytrącanie minerałów). Inny kierunek przebiegu reakcji (wytrącanie minerałów) wskazywany jest przeważnie z użyciem bazy pitzer.dat, jednakże skromna liczba dostępnych minerałów znacznie ogranicza możliwości wykorzystania tej bazy danych. Zwłaszcza brak danych dotyczących minerałów zawierających żelazo powoduje obniżenie przydatności tej bazy danych do przewidywania zjawisk towarzyszących zatłaczaniu wód separatorowych.

Pomimo pewnych niezgodności i braku wystarczającej ilości zweryfikowanych danych program PHREEQC może dostarczyć cennych informacji dotyczących procesów przebiegających w złożu i być pomocny podczas planowania zakresu modyfikacji parametrów wód separatorowych przed ich zatłoczeniem do horyzontu chłonnego. 


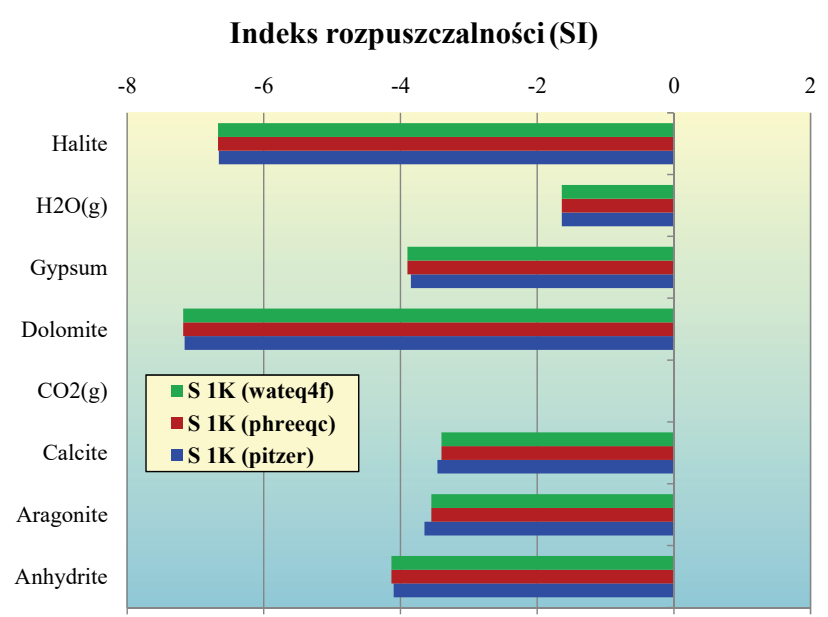

Indeks rozpuszczalności (SI)

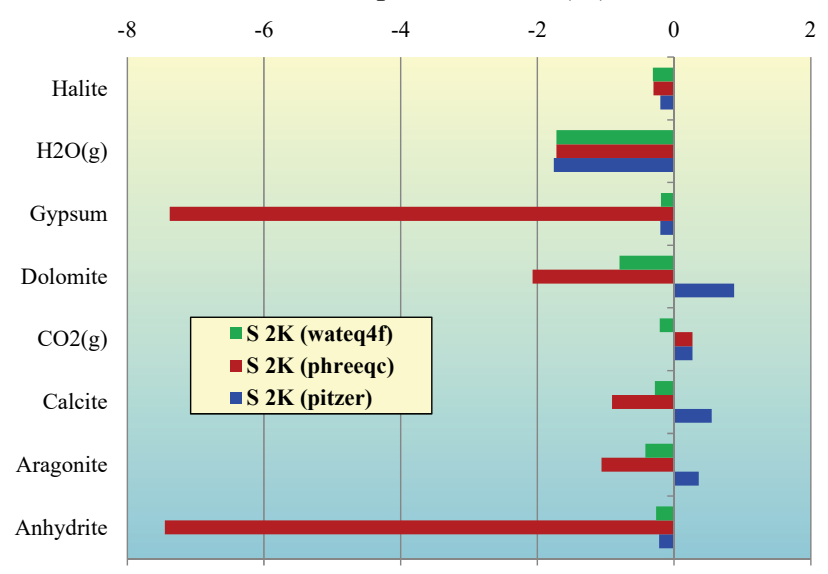

\section{Indeks rozpuszczalności (SI)}

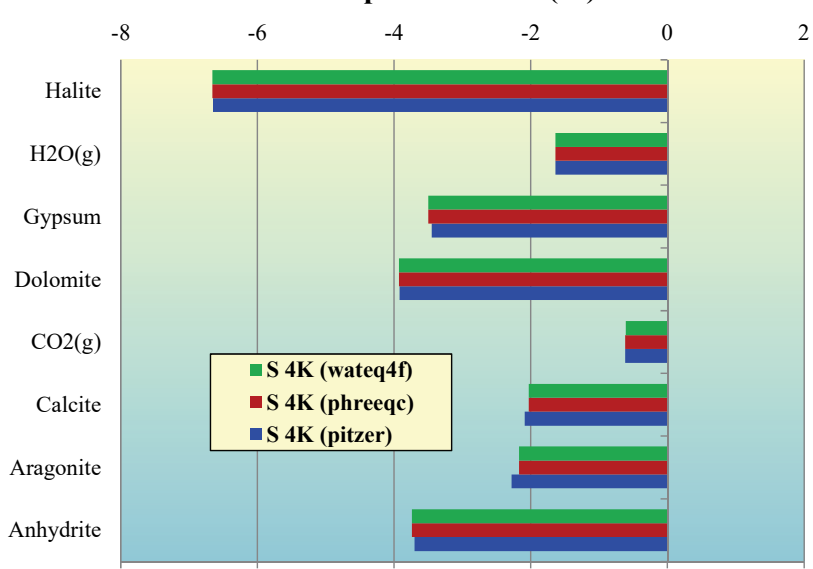

Indeks rozpuszczalności (SI)

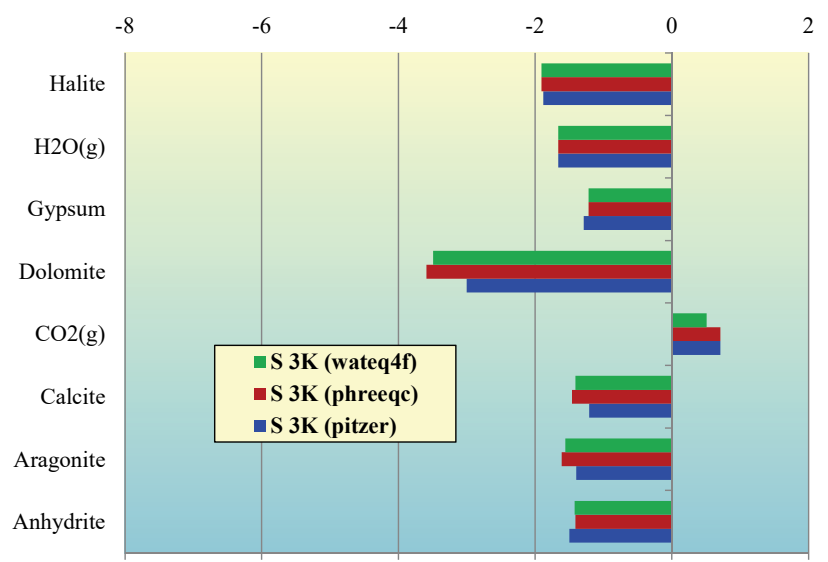

Rys. 6. Porównanie obliczonych wartości SI minerałów obecnych w trzech bazach danych dla próbek wód (S1K, S2K, S3K i S4K)

Fig. 6. Comparison of the calculated SI values of minerals present in three databases for water samples (S1K, S2K, S3K and S4K)

Artykuł powstał na podstawie pracy pt. Symulacja procesów mieszania się wód złożowych z wykorzystaniem wybranego oprogramowania - praca INiG - PIB na zlecenie MNiSW; nr zlecenia: 0068/KE/2020, nr archiwalny: DK-4100-0056/2020.

\section{Literatura}

Abdelaziz R., Merkel B.J., Zambrano-Bigiarini M., Nair S., 2019. Particle swarm optimization for the estimation of surface complexation constants with the geochemical model PHREEQC-3.1.2. Geoscientific Model Development, 12: 167-177. DOI: 10.5194/ gmd-12-167-2019.

Ball J.W., Nordstrom D.K., 1991. WATEQ4F - User's manual with revised thermodynamic data base and test cases for calculating speciation of major, trace and redox elements in natural waters. U.S. Geological Survey Open-File Report, 90-129: 1-185.

Cebulski D., Urbaniec A., Łukaszewski P., 2017. Możliwości zastosowania wybranych metod badawczych do określania własności i cech strukturalnych soli kamiennych. Prace Naukowe Instytutu Nafty i Gazu-Państwowego Instytutu Badawczego, 217: 1-191. DOI: $10.18668 /$ PN2017.217.

Daneshgar S., Buttafava A., Callegari A., Capodaglio A.G., 2018. Simulations and Laboratory Tests for Assessing Phosphorus Recovery Efficiency from Sewage Sludge. Resources, 7(3): 54. DOI: 10.3390/resources7030054.

Dobrzyński D., 2006. Modelowanie geochemiczne narzędziem poznania geochemii systemów wód podziemnych. Przykłady zastosowań, aktualny stan w Polsce. Przeglad Geologiczny, 54(11): 976-981.

Fowler S.J., Kosakowski G., Driesner T., Kulik D.A., Wagner T., Wilhelm S., Masset O., 2016. Numerical Simulation of Reactive Fluid Flow on Unstructured Meshes. Transport in Porous Media, 112: 283-312. DOI: 10.1007/s11242-016-0645-7.

Gao Y., Pu S., Zheng C., Yi S., 2019. An improved method for the calculation of unsaturated-saturated water flow by coupling the FEM and FDM. Scientific Reports, 9, 14995. DOI: 10.1038/ s41598-019-51405-4.

Guorui W., Qiang W., Zizhong Y., Na Z., Chengbao D., Xia C. Hui W., 2019. Fine Prediction for Mine Water Inflow on Basis of Visual Modflow. International Journal of Oil, Gas and Coal Engineering, 7(2): 52-59. DOI: 10.11648/j.ogce.20190702.12.

He W., Xie Z., Lu W., Huang M., Ma J., 2019. Comparative analysis on floc growth behaviors during ballasted flocculation by using aluminum sulphate (AS) and polyaluminum chloride (PACl) as coagulants. Separation and Purification Technology, 213: 176-185. DOI: 10.1016/j.seppur.2018.12.043.

Heredia D.J., 2017. Improvement of the numerical capacities of simulation tools for reactive transport modeling in porous media. Earth Sciences. Université Rennes 1.

$\mathrm{Hu}$ Y., Mackay E., 2016. Modelling of geochemical reactions during smart water injection in carbonate reservoirs. European Association of Geoscientists \& Engineers, 1-5. DOI: 10.3997/2214-4609.201600768. 
Huber P., Neyret C., Fourest E., 2017. Implementation of the anaerobic digestion model (ADM1) in the PHREEQC chemistry engine. Water Science \& Technology, 76(5-6): 1090-1103. DOI: 10.2166/ wst.2017.282.

Jakóbczyk S., Kowalczyk A., 2011. Zastosowanie modelowania geochemicznego do oceny warunków kształtowania się składu chemicznego wód podziemnych w rejonie ujęcia Gliwice Łabędy. Biuletyn Państwowego Instytutu Geologicznego, 445: 217-226.

Jakubowicz P., 2010. Wybrane problemy zagospodarowania odpadowych wód kopalnianych. Nafta-Gaz, 5: 383-389.

Jakubowicz P., Steliga T., 2012. Assessment of the Main Threats to Injection Well Damage Caused by Reservoir Waters using AquaChem Software as well as Laboratory Tests Application. Nafta-Gaz, 10: 655-660.

Jakubowicz P., Steliga T., 2017. Efektywność działania nowoczesnych koagulantów glinowych w warunkach obniżonego $\mathrm{pH}$ wód z formacji łupkowych. Nafta-Gaz, 3: 169-176. DOI: 10.18668/ NG.2017.03.04

Kluk D., 2011. Badania procesu mieszania wód zatłaczanych z wodami złożowymi o zróżnicowanych potencjałach elektrochemicznych. Nafta-Gaz, 2: 98-106.

Klunk M.A., Damiani L.H., Feller G., Conceição R.V., Abel M., De Ros L.F., 2015. Geochemical modeling of diagenetic reactions in Snorre Field reservoir sandstones: a comparative study of computer codes. Brazilian Journal of Geology, 45(1). DOI: 10.1590/2317-4889201530145.

Lassin A., Andre L., Lach A., 2017. Considerations about the building of a thermodynamic database for the chemical description of highly saline systems. Procedia Earth and Planetary Science, 17: 304-307. DOI: 10.1515/gospo-2017-0017.

Lewkiewicz-Małysa A., Winid B., 2011. Geologiczne i geochemiczne aspekty chłonności otworów wykorzystywanych do zatłaczania wód złożowych. Środkowo-Pomorskie Towarzystwo Naukowe Ochrony Środowiska. Rocznik Ochrona Środowiska, 13: 1985-1999.

Li L., Wu Y., Chong S., Wen Q., 2020. The application of TOUGHREACT in the field of energy and environment. IOP Conf. Ser.: Earth and Environmental Science, 569. DOI: 10.1088/1755-1315/569/1/012093.

Li X., He X., Yang G., Zhao L., Chen S., Wang C., Chen J., Yang M., 2016. Study of groundwater using visual MODFLOW in the Manas River Basin, China. Water Policy, 18(5): 1139-1154. DOI: 10.2166/wp.2016.180.

Lubaś J., Stopa J., Warnecki M., Wojnicki M., 2019. Możliwości zastosowania zaawansowanych metod wspomagania wydobycia ropy naftowej ze złóż dojrzałych. Nafta-Gaz, 1: 24-28. DOI: 10.18668/NG.2019.01.04.

Muggeridge A., Cockin A., Webb K., Frampton H., Collins I., Moulds T., Salino P., 2014. Recovery rates, enhanced oil recovery and technological limits. Phil. Trans. R. Soc. A., 372: 1-25. DOI: $10.1098 /$ rsta.2012.0320.

Parkhurst D.L., Appelo C.A.J., 1999. User's guide to PHREEQC (Version 2) - A computer program for speciation, batch-reaction, one-dimensional transport, and inverse geochemical calculations. U.S. Geological Survey Water-Resources Investigations Report, 99-4259: 1-312.

Parkhurst D.L., Thorstenson D.C., Plummer L.N., 1980. PHREEQE A computer program for geochemical calculations. U.S. Geological Survey Water-Resources Investigations Report, 80-96: 1-195. (Revised and reprinted August, 1990.)

Pitzer K.S., 1973. Thermodynamics of electrolytes - 1. Theoretical basis and general equations. Journal of Physical Chemistry, 77(2): 268-277.
Plummer L.N., Parkhurst D.L., Fleming G.W., Dunkle S.A., 1988. A computer program incorporating Pitzer's equations for calculation of geochemical reactions in brines. U.S. Geological Survey Water-Resources Investigations Report, 88-4153: 1-310.

Ren J.M., Yang Y., Hu X.W., 2011. Application of GIS and FEFLOW in Forecasting Groundwater Flow Field of Minqin Basin. Advanced Materials Research, 368-373: 2128-2131.

Rubinstein J.L., Mahani A.B., 2015. Myths and Facts on Wastewater Injection, Hydraulic Fracturing, Enhanced Oil Recovery, and Induced Seismicity. Seismological Research Letters, 86(4): 1060-1067. DOI: 10.1785/0220150067.

Steliga T., Jakubowicz P., Kapusta P., 2015. Changes in toxicity during treatment of wastewater from oil plant contaminated with petroleum hydrocarbons. Journal of Chemical Technology and Biotechnology, 90: 1408-1418. DOI: 10.1002/jctb.4442.

Teh C.Y., Budiman P.M., Shak K.P.Y., Wu T.Y., 2016. Recent Advancement of Coagulation-Flocculation and Its Application in Wastewater Treatment. Industrial \& Engineering Chemistry Research, 55(16): 4363-4389. DOI: 10.1021/acs.iecr.5b04703.

Uliasz-Misiak B., Chruszcz-Lipska K., 2017. Aspekty hydrogeochemiczne związane z mieszaniem wód złożowych zatłaczanych do złoża węglowodorów. Gospodarka Surowcami Mineralnymi, 33(2): 69-80. DOI: 10.1515/gospo-2017-0017.

Wanner C., Eichinger F., Jahrfeld T., Diamond L.W., 2017. Unraveling the formation of large amounts of calcite scaling in geothermal wells in the Bavarian Molasse Basin: a reactive transport modeling approach. Procedia Earth and Planetary Science, 17: 344-347. DOI: 10.1016/j.proeps.2016.12.087.

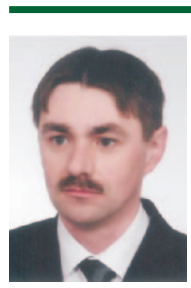

Dr Piotr JAKUBOWICZ

Adiunkt w Zakładzie Technologii Eksploatacji Płynów Złożowych

Instytut Nafty i Gazu - Państwowy Instytut Badawczy ul. Lubicz 25 A

31-503 Kraków

E-mail: piotr.jakubowicz@inig.pl

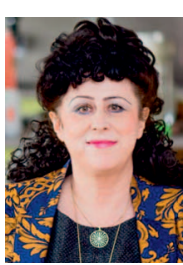

Dr hab. inż. Teresa STELIGA, prof. INiG - PIB Kierownik Zakładu Technologii Eksploatacji Płynów Złożowych Instytut Nafty i Gazu - Państwowy Instytut Badawczy ul. Lubicz 25 A 31-503 Kraków E-mail: teresa.steliga@inig.pl

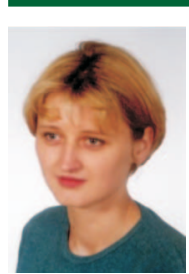

Dr inż. Dorota KLUK

Adiunkt w Zakładzie Technologii Eksploatacji Płynów Złożowych Instytut Nafty i Gazu - Państwowy Instytut Badawczy ul. Lubicz $25 \mathrm{~A}$

31-503 Kraków

E-mail:dorota.kluk@inig.pl

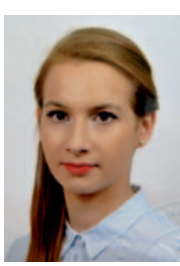

Mgr Katarzyna WOJTOWICZ

Asystent w Zakładzie Technologii Eksploatacji Płynów Złożowych

Instytut Nafty i Gazu - Państwowy Instytut Badawczy ul. Lubicz 25 A

31-503 Kraków

E-mail: katarzyna.wojtowicz@inig.pl 